Journal of Teacher Education for Sustainability, vol. 17, no. 2, pp. 44-52, 2015

\title{
The Challenges of Global Citizenship for Worldview Education. The Perspective of Social Sustainability
}

\author{
Siebren Miedema and Gerdien Bertram-Troost \\ VU University Amsterdam, the Netherlands
}

\begin{abstract}
In this paper the authors briefly present what their theoretical reflections and empirical research has yielded in respect to citizenship education and religious education. The theoretical as well as political and practical questions of the relationship of global citizenship and worldview education are scrutinized. The main focus is on the issue whether there is or could be a connection between the concepts of 'worldview education' and 'global citizenship education' from the point of view of inclusivity in respect to both concepts. Habermas's distinction between the concepts of democratic state citizenship and global or cosmopolitan citizenship is conceptually helpful. The authors also take into account the question of whether there is a certain educational, political or religious necessity on a national as well as global level to deal with this possible relationship as viewed through the lens of social sustainability.
\end{abstract}

Keywords: global citizenship education, democratic state citizenship, worldview education, inclusivity, social sustainability

In several publications the authors have paid attention to the relationship that exists between citizenship education and religious or worldview education in schools (Miedema, 2012; Miedema \& Bertram-Troost, 2008), and quite recently the authors have also related it to human rights education (Miedema \& Bertram-Troost, 2014). Reflecting further upon the notion of citizenship that the authors have used in their work, they realize that they have conceptualized that notion mostly in terms of their own country, the Netherlands, or in the context of the EC-funded empirical REDCo research project "Religion in Education: A Contribution to Dialogue or a Factor of Conflict in Transforming Societies of European Countries" within the framework of the eight particular countries that participated in that research being done in Estonia, Germany, Russia, Norway, the United Kingdom, the Netherlands, France and Spain (for an overview of this project see Jackson, Miedema, Weisse, \& Williame, 2007). So, a kind of particularistic conception of the concept of 'citizenship' strongly related to the nation state or to West-Europe - even in a more or less sophisticated form - was presupposed in the present authors' analysis combined with a plea for and reference to 
contextuality. Taking into account several developments on a global scale the authors think that it is necessary to broaden the scope now to make it more inclusive and try to imagine what a notion like 'global citizenship' might mean if related to the inclusive concept of worldview education.

In this paper the authors will first briefly present what their theoretical reflections and empirical research has yielded in respect to citizenship education and religious education. Then they will scrutinize the theoretical as well as political and practical question of the relationship between the global citizenship and worldview education. Thus, the main focus is on the issue of whether there is or could be a connection between the concepts of 'worldview education' and the very notion of 'global citizenship education', and to scrutinize the question whether there is a certain educational, political or religious necessity to imagine this possible relationship with an eye on the perspective of social sustainability.

The next section will commence with the relationships between the citizenship education and religious education or, using the term the authors prefer - 'worldview education'.

\section{Citizenship Education and Worldview Education}

The authors are strongly in favor of the concept of 'maximal citizenship education' as outlined by the late Terrence McLaughlin (see Miedema, 2014a; Miedema \& BertramTroost, 2014), because it offers

a substantial notion of 'education for citizenship' in the context of the diversity of a pluralistic democratic society, a notion ... 'thick' or substantial enough to satisfy the communal demands of citizenship, yet compatible with liberal demands concerning the development of critical rationality by citizens and satisfaction of the demands of justice relating to diversity. (1992, p. 235, authors' italics)

Such a society, according to McLaughlin, should seek to find a balance between social and cultural diversity with cohesion. A maximal approach to citizenship education is characterized by an emphasis on active learning and inclusion, is interactive, valuesbased and process led, allowing students to develop and articulate their own opinions and to engage in debate, dialogue and encounter. It presupposes not only teaching and learning about civic subject matter as in the minimal conception of citizenship, but also teaching and learning from subject matter, practices and experiences in respect to the pupils' civic formation. In this constructivist conception the individual's identity, individuation or subjectification is highly important and interpreted as dynamic instead of static, and it is a matter for incessant development, debate and redefinition. Maximal citizenship education "requires a considerable degree of explicit understanding of democratic principles, values and procedures on the part of the citizen, together with the dispositions and capacities required for participation in democratic citizenship generously conceived" (McLaughlin, 1992, p. 237), both in the school and society at large. Besides, the concept of maximal citizenship education offers the possibility to include religious content or aspects of worldviews that are of value in the different curriculum components of the educational program. This is fully compatible with what has been claimed elsewhere to be the aim of education in schools for a transformative 
pedagogy, meaning that every child and youngster in every school should be able to develop her or his personal identity or personhood (Biesta \& Miedema, 2002; Miedema, 2014 b). Thus, maximal citizenship education can include and also should imply the fostering of the religious and/or worldview component of the child's personhood formation.

In the title of this section we already used the term 'worldview' instead of the concept of 'religion'. The reason for this preference is that not everyone is an adherent of a religious view on life, the world and humanity, thus acknowledging the presence of a transcendental entity. Notice, for example, that humanism and atheism are worldviews but that they are not religions. We use the concept 'worldview' with 'religion' as a subconcept of it, and define it as the system, which is always subjected to changes, of implicit and explicit views and feelings of an individual in relation to human life. 'Views and feelings in relation to human life' can refer to everything with which people can be occupied with and what can be important to them. In empirical research with students we use a short 'stipulative definition' namely: "A worldview is the way one looks at life" (Bertram-Troost, de Roos, \& Miedema, 2006, p. 311). The use of the concept of 'worldview' may help to avoid strong secularist approaches that direct themselves against religion. In these views religions and worldviews are strictly separated from the public and the social domain and positioned in the private realm of the family and/or religious communities, and should be completely left out of the curriculum of the school. However, everyone has at least a personal worldview that is a view on life, the world and humanity providing answers to existential questions. Such personal worldviews are sometimes but not always directly influenced by an organized worldview, and this should be pedagogically taken into account as we have claimed elsewhere (see Van der Kooij, de Ruyter, \& Miedema, 2013). The inclusive concept of 'worldview' can also prevent exclusivist claims leading, for example, to preferential argumentation in paying attention to one religion only, for instance the Christian one, or to one worldview - the liberal-democrat one. Both cases can be interpreted as the worldview or religious claims against, for instance, the universal claim in human rights of children that they have the right of self-development and self-appropriation. A thick conception of worldview education includes teaching and learning about and from worldviews and/or religions, and this is in contrast to a thin conception that is just teaching and learning about worldviews and/or religions. Worldviews and religions may manifest themselves in organized as well as personal forms, and with or without a relationship between the personal and one particular organized form. Increasing individualism and awareness of the diversity of organized worldviews due to globalization have stimulated the construction of people's own individualized personal worldview. This construction process is characterized as the 'bricolage' (Hervieu-Léger, 2006).

During the first decade of the $21^{\text {st }}$ century the Council of Europe has given a strong impetus to the democratic citizenship education in the member states, for example, in the Charter on Education for Democratic Citizenship and Human Rights Education (Council of Europe, 2010). This momentum has been steadily acknowledged in relationship to the (inter)religious education combined with intercultural education. The aim for this pedagogical, educational, as well political program was to strengthen the potentialities of strong, open and inclusive thinking of children and youngsters regarding religion and worldview, and to tackle the dangers of religions and worldviews within the setting of the schools (see Jackson, Miedema, Weisse, \& Willaime, 2007). Schools, 
being embryonic societies as John Dewey has characterized them (Dewey, 1897/1972; 1916 ; 1927), should embody and practice the constituent elements of real participative and deliberative democracies. Following and further elaborating on Dewey's pragmatist view, pedagogically speaking and from a societal as well as political perspective it is desirable that children already in the embryonic society of the school, experience, are confronted by and become acquainted with the other children's religious or worldview, cultural, ethnic, economical backgrounds, ideas, experiences, practices, situations, and contexts. Seeing the impact of religious/worldview and the influence of the political, cultural and economic domains both locally and globally, children can also benefit from such experiences and insights when they encounter religious/worldview, cultural, ethnic and political 'others' in society at large, and around the globe. However, the school has its own place here sui generis. So, from a societal as well as pedagogical point of view, all schools should be willing - and in our opinion should be obliged - to aim for fostering democratic citizenship education, interreligious or inter-worldview education, and human rights education. Thereby, bringing about mutual respect and understanding and stimulating the development of democratic citizenship formation, worldview citizenship formation, and human rights formation, schools can improve the global and sustainable dynamics.

On the basis of a special issue of the Dutch academic journal Pedagogiek, edited by the present authors together with Wiel Veugelers (see Miedema, Bertram-Troost, \& Veugelers, 2013) we can make up the balance sheet of how worldview education is broadly favored and practiced nowadays in schools in France, England, the Netherlands, Belgium and in particular parts of Germany. Just to limit ourselves to the Netherlands here: all schools, that are denominational as well as public schools are invited by the government to relate citizenship education to worldview education. For the more orthodox Protestant and Roman-Catholic schools this creates the challenge to really deal with religious and worldview diversity instead of taking an exclusive mono-religious stance. It challenges public schools to deal with the diversity of worldviews and religions in an active pedagogical way. So, instead of acknowledging that there is worldview diversity in the school, the teachers should take this up in their pedagogical and didactical practices. The core issue is that in these schools the pupils' self-responsible self-determination regarding worldview and religions (Miedema, 2014a, p. 371) should be seen as the main pedagogical aim of a values-based curriculum.

In the next section of this paper the authors will deal with the question of whether there is or could be a connection between the concepts of 'worldview education' and the very notion of 'global citizenship education', and will scrutinize the question whether there is the necessity and the possibility to relate this to social sustainability.

\section{Broadening the Scope with the Notions of Global Citizenship and Social Sustainability}

We notice that there are some worldwide problems related also but fortunately not exclusively to religions and worldviews that we have to face today. Just to mention couple of them here, one can recall the recent attacks in Paris on Charlie Hebdo, the travel of jihadists from the West to Syria and Iraq as well as the problems associated with returnees from these countries and jihadists that still stay in their own countries. These problems do not ask for exclusive particularistic approaches or for an exclusive 
focus on national or even regional identities. On the contrary, these problems do concern every human being, humankind and humanity in its broadest global sense. The current global constellation is, in our view, triggered by the question of the necessity to think and act more globally in religious education and worldview education in order to prevent, for example, the development of narrow minded or radicalized children and young people. For that reason it is necessary to imagine how democratic state citizenship education and global citizenship education could form a continuum.

These issues also immediately relate to the very concept of social sustainability. They present some of the greatest challenges of our time, are part and parcel of every nation in the world, do concern every human being, humankind and humanity in general and on a global scale, they have to do with the human shaping of the world by means of globalisation, and connect at least to political and social learning processes due to their intercultural and transcultural nature (see Brunold, 2015).

It is our view that the role and function of human rights education might be of great help here to broaden the perspective on citizenship toward the global citizenship. If a government would take the responsibility for an inclusive concept of citizenship education seriously, it should mean that without any governmental preference for a particular worldview or religion, each government could assume what we characterize as the political-pedagogical responsibility to stimulate the policy of and practice in schools to foster religious or worldview education as a part of an integral citizenship education (see Miedema \& Bertram-Troost, 2008). Adding to this political-pedagogical responsibility, the responsibility for human rights education as an integral part of this should imply that the state should feel obliged to stimulate in schools the building and defense of a universal culture of human rights in society and globally, with a view on the promotion and protection of human rights and fundamental freedoms in a societal and/or global way.

We will provide an example from our own country, the Netherlands, to show why stressing the universality of human rights and children's rights is an ongoing need. Right wing parties but also liberal democrats and Christian democrats are now and then trying to particularize - or in our view even to provincialize or nationalize - the interpretation of human and children's right in respect to strangers. Here we have the tension between the open universality on a national and local level versus segregated or closed particularity. Or to put it differently: the tension is between thick constitutionalism including transnational focus on human rights and especially the position of the individual versus thin constitutionalism with a national focus on the national context, particularly in terms of heritage and culture in a tense relationship with human rights (see Miedema \& Bertram-Troost, 2014).

What might be very helpful here is the way Jürgen Habermas in 1992 has dealt with these tensions between particularistic and global notions of citizenship (see also Miedema \& Bertram-Troost, 2008). He observed that in the 80s and early 90s of the 20 th century most prosperous countries in West-Europe were confronted with a growing stream of immigrants and refugees from poor and/or turbulent areas of South and East Europe, the Middle East, and Africa. Talking about citizenship and national identity was primarily reinforced by the fear that the state of affluence or the welfare states of these prosperous countries were threatened by the incoming masses. Habermas has so adequately characterized this mechanism as the 'chauvinism of affluence' (Habermas, 1996, p. 507). He introduced a distinction between two conceptions of the concept of 
'citizenship': a classical-liberal view stressing private citizenship and the sovereignity of the nation state, and a democratic-liberal view pointing to social citizenship in line with the welfare state interpretations at the level of the state. In respect with these two conceptions Habermas stated:

The identity of the political community, which also must not be violated by immigration, depends primarily on the legal principles anchored in the political culture and not on an ethnic-cultural form of life as a whole. It follows that one must expect only that immigrants willingly engage in the political culture of their new home, without necessarily abandoning the cultural life specific to their country of origin. The political acculturation demanded of them does not extend to the whole of their socialization. Rather, by importing new forms of life, immigrants can expand or multiply the perspectives from which the shared political constitution must be interpreted. (1996, pp. 513-514)

Habermas takes a stance against any exclusive particularistic interpretation of citizenship in terms of a specific ethnic-cultural identity, and is in favour of a political or inter-subjective meaning of citizenship. The argument for that option was and still is that the identity of a political community is primarily embedded in the principle of the political culture, and not in a specific ethnic-cultural way of life. Cultural and political claims are, however, not completely separable. They overlap each other and influence each other's territory. Such a conception of democratic or social citizenship offers the possibility and can pave the way for a global citizenship. The worldwide nature of problems we have to face does not ask for an exclusive particularistic formulation of the problem, not even for an exclusive focus on national identity. Those problems do concern every human being. For that reason it is necessary that democratic state citizenship and global citizenship form a continuum (Miedema \& Bertram-Troost, 2008).

From the perspective of the relationship between the democratic state citizenship and global citizenship it is useful to refer here to the highly insightful debate between Martha Nussbaum and Charles Taylor in the midst of the 90s in the last century, because that discussion makes clear that two notions of democratic state citizenship and global citizenship should not be separated (see in extenso Papastephanou, 2013 who pointed us to this debate).

In the article by Nussbaum (1994) patriotism and cosmopolitanism were conceptualized as mutually exclusive concepts, and it is clearly stated that she is in favour of the latter concept and this to the detriment of the first one is due to the risks of fanaticism that easily come with patriotism. In his reaction to this article Taylor (1996) criticizes this drastic choice for cosmopolitanism and states that we need both in the modern world, because "modern democratic states are extremely exigent common enterprises in self-rule. They require a great deal of their members, demanding much greater solidarity towards compatriots than towards humanity in general. We cannot make a success of these enterprises without strong common identification" (Taylor, 1996, p. 119). Taylor wants to fight for the kind of patriotism which is open to universal solidarities against other, more closed kinds (see Papastephanou, 2013, p. 176). In her later writings Nussbaum's view converges, however, strongly with Taylor's conviction when she, for instance, asserts that she envisages a complicated dialogue between local attachments and loyalty to humanity (Papastephanou, 2013, p. 167). 
Using the concept of 'worldview' as an embracing concept in respect to 'religion' and making it all inclusive that way due to its broadened denotation, the same could analytically be said regarding democratic state citizenship and global citizenship. The latter one is the broadened, more embracing or inclusive one but always linked to the first form of citizenship.

Yet, we have also broadened our scope by intertwining a strong relationship of worldview education, citizenship education and human rights education with social sustainability positioned on a national as well as a global level. Along these lines elements of what might be coined as a pedagogy of social sustainability could strengthen our transformative pedagogical approach (Miedema, 2014b), thus helping pupils to see how the world could be shaped locally and globally with a strong concern for every human being, humankind and humanity in general and on a global scale and making them sensitive to the political and social, that is - intercultural, transcultural and interreligious components of these processes and practises.

\section{Conclusion}

In sum, in this article we have articulated our preference for the notion 'worldview' due to the inclusivity of the denotation of this concept, and because, in pedagogical terms, it can stimulate dialogue, encounter and participation, leading to the participatory democracy in a Deweyan sense (Dewey, 1916, pp. 86-88). The contemporary global problems related also but not exclusively to religion and worldview, next to ecological issues, urges us, in our view, to broaden the range of citizenship and to make it a more inclusive concept by means of the concept of 'global citizenship', just like 'worldview education' is a broader term than 'religious education'.

We have argued that human rights education can also foster a universal and global stance as an antidote against exclusive particularistic interpretations of citizenship and in favour of an inter-subjective interpretation of citizenship. Democratic state citizenship education combined with global citizenship education can strengthen such learning processes. This can be practiced in schools in combination with an inclusive stance to religions and worldviews. Combined with social sustainability this might help pupils to see how the world could be shaped locally and globally with a strong concern for every human being, humankind and humanity in general and on a global scale. These are the challenges of global citizenship for worldview education but also the challenges of worldview education for global citizenship from a social sustainable perspective.

Finally, there are some social sustainable institutional pre-conditions in demand that specify the embracing pedagogy implicated in our plea. First, all stakeholders (ministry of education, politicians, school leaders, teachers and parents) should be convinced that edification or Bildung is the main aim of what is going on in schools instead of only the so-called 'core subjects' such as reading, writing and mathematics or the preparation for the knowledge-based economy in terms of employability. It also presupposes school administrators with a pedagogical vision who are able to communicate and share it with their staff in order to build transformative practices. We also need teacher colleges where teachers in statu nascendi can develop their knowledge, skills and attitudes and who can become pedagogical professionals able to embrace transformative pedagogical situations and relations in their schools together with their colleagues. 


\section{References}

Bertram-Troost, G. D., de Roos, S. A., \& Miedema, S. (2006). Religious identity development of adolescents in religiously affiliated schools: A theoretical foundation for empirical research. Journal of Beliefs and Values, 27(3), 303-314.

Biesta, G. J. J., \& Miedema, S. (2002). Instruction or pedagogy? The need for a transformative conception of education. Teaching and Teacher Education, 18, 173181.

Brunold, A. O. (2015). Civic education for sustainable development and global learning in German didactics and curricula of secondary education. Keynote presented in the $13^{\text {th }}$ International JTEFS/BBCC Conference "Sustainable Development. Culture. Education”. Riga, Latvia, May 6, 2015.

Council of Europe. (2010). Charter on education for democratic citizenship and human rights education. Strasbourg: Council of Europe.

Dewey, J. (1897/1972). My pedagogic creed. In J. A. Boydston (Ed.), John Dewey. The early works. Volume 5 (pp. 84-95). Carbondale and Edwardsville: Southern Illinois University Press.

Dewey, J. (1916). Democracy and education. An introduction to the philosophy of education. New York: The Free Press.

Dewey, J. (1927). The public and its problems. New York: Henry Holt and Company.

Habermas, J. (1996). Between facts and norms: Contributions to a discourse theory of law and democracy. Cambridge, MA: MIT Press.

Hervieu-Léger, D. (2006). In search of certainties: The paradoxes of religiosity in societies of high modernity. The Hedgehog Review, 8(1-2), 59-68.

Jackson, R., Miedema, S., Weisse, W., \& Willaime, J.-P. (Eds.) (2007). Religion and education in Europe. Developments, contexts and debates. Münster/New York/ München/Berlin: Waxmann.

McLaughlin, T. H. (1992). Citizenship, diversity and education: A philosophical perspective. Journal of Moral Education, 21(3), 235-250.

Miedema, S. (2012). Maximal citizenship education and interreligious education in common schools. In H. A. Alexander \& A. K. Agbaria (Eds.), Commitment, character, and citizenship. Religious education in liberal democracy (pp. 96-102). London/ New York: Routledge.

Miedema, S. (2014a). “Coming out religiously!” Religion, the public sphere, and religious identity formation. Religious Education, 109(4), 362-377.

Miedema, S. (2014b). From religious education to worldview education and beyond: The strength of a transformative pedagogical paradigm. Journal for the Study of Religion, 27(1), 82-103.

Miedema, S. \& Bertram-Troost, G. D. (2008). Democratic citizenship and religious education: Challenges and perspectives for schools in the Netherlands. British Journal of Religious Education, 30(2), 123-132.

Miedema, S. \& Bertram-Troost, G. D. (2014). Reconciling the civic, the sacred, and the just in critical-pragmatic education. Religious Education, 109(1), 72-80.

Miedema, S., Bertram-Troost, G. D., \& Veugelers, W. (Eds.) (2013). Themanummer: Onderwijs, levensbeschouwing, en het publieke domein [Special issue: Education, worldview and the public square]. Pedagogiek, 33(2), 73-186.

Nussbaum, M. (1994). Patriotism and cosmopolitanism. Boston Review, 19(5), 3-6. 
Papastephanou, M. (2013). Cosmopolitanism discarded: Martha Nussbaum's patriotic education and the inward-outward distinction. Ethics and Education, 8(2), 166178.

Taylor, C. (1996). Why democracy needs patriotism. In J. Cohen (Ed.), For love of country: Debating the limits of patriotism (pp. 119-121). Boston: Beacon Press.

Van der Kooij, J. C., de Ruyter, D. J., \& Miedema, S. (2013). "Worldview": The meaning of the concept and the impact on religious education. Religious Education, 108(2), 210-228.

Correspondence concerning this paper should be addressed to Prof. Dr. Siebren Miedema, Faculty of Behavioural and Movement Sciences, Section of Research and Theory in Education, VU University Amsterdam, Van der Boechorststraat 1, 1081 BT, Amsterdam, The Netherlands. Email: s.miedema@vu.nl 